\title{
Social research evolution in management accounting: reflection using Bunge's theory
}

\author{
Mercedes Barrachina $^{\mathrm{a}}$, Vicente Ripoll ${ }^{\mathrm{a}}$, Susana Gago ${ }^{\mathrm{b}, *}$ \\ ${ }^{a}$ University of Valencia, Valencia, Spain \\ ${ }^{\mathrm{b}}$ Departmamento de Economia de la Empresa, University Carlos III of Madrid, Calle, Madrid 126, Spain
}

Received 15 December 2002; accepted 30 January 2003

\begin{abstract}
Actually Management Accounting is considered for an important group of researchers as a social science. This is a consequence of an evolution from an economic view to social-oriented perspectives. Following Mario Bunge's theory, we establish that break point in 1980s. Until 1980s, the accounting research was dominated by an economic analysis with both utilitarian and cognitive objectives. The scientific growth was in surface, without any relevant change in the foundations of Management Accounting. The development of new concerns regarding social implications promotes a growth in depth in the 1980s. Socio-economic analysis, both in interpretative and critical research, is developed following utilitarian and cognitive objectives.

We defend that Management Accounting, to consolidate its status as a social science, needs an evolutionary, reflexive and trans-disciplinary thinking, in both theoretical and empirical dimension. Utilitar ian and cognitive approaches must be developed and in a coordinated way. Dialogue between different theoretical perspectives will support the utilitarian objective. Dialogue between different methods and findings, in particular case studies, will contribute to both utilitarian and cognitive dimensions.

(C) 2003 Elsevier Science Ltd. All rights reserved.
\end{abstract}

Keywords Research evolution; Management accounting; Social science; Bunge's theory; Utilitarian objective; Cognitive objective; Growth in depth; Growth in surface; Case studies

\section{Introduction: motivation and aim of the study}

A part of the accounting community has been aware regarding social issues (Baker and Bettner, 1997; Hopwood, 1987). That new literature defends the scientific benefits that may

\footnotetext{
* Corresponding author. Tel.: +34 91624 5834; fax: +34 916245834 .

E mail address efcsgago@usc es (S. Gago).
} 
derive from expanding the sphere of accounting studies from the economic or technical dimension to the social dimension.

The perspective in the study of Management Accounting is, then, widened. The most orthodox conceptions defend that economy and economic reality are decisive factors (Beckett, 1964; Belkaoui, 1985, 1990; Cañibano and Gonzalo, 1997). The alternative approaches, that we might call non-orthodox, put emphasis on social aspects such as culture, ideology, power, social relationships and so on (Mathews, 1993; Morgan, 1988; Nahapiet, 1988; Perera, 1989; Thomas, 1989).

Among the non-orthodox approaches, critical perspectives understand that accountants (researchers and practitioners) must be not only conscious of social aspects but also act in consequence. However, this is still a minority position. There is a lack of interpretative and critical research in mainstream accounting (Baker and Bettner, 1997; Howard and Nikolai, 1983; Lapsley and Mitchell, 1994; Scapens, 1994).

The new social concern has brought us to reconsider the scientific status of Management Accounting. In this paper we debate the evolution of Management Accounting as a science and, in particular, as a social science. We assess the state of current research being conducted in Management Accounting. We used the theoretical framework of Mario Bunge (1972, 1973, 1983). Bunge's theory facilitates an analysis of the orientation, quality and aims that scientific research activity possesses. That study has enabled us to draw about the current scientific situation and possible evolution in Management Accounting.

\section{Scientific development in Management Accounting}

\subsection{Bunge's theoretical framework}

The paradigm or common theory of Kuhn (1962) was the predominant idea in the scientific accounting community during many years. His thesis about periods of normal science and periods of crisis attempted to explain the accumulation and development of scientific knowledge. Others resorted to Popper's falsationism (1967, 1973). Over the past few decades this situation has undergone a certain evolution with the acknowledgment of the theses by Lakatos $(1974,1975)$, Stegmüller (1979), and that of Bunge (1983).

Bunge $(1972,1973,1983)$ proposes a doctrine referring to scientific development and the nature and typology of research in a social science. His framework is built upon two contributions. First, he identifies two types of programs in the evolution of scientific knowledge, the on-surface research program and the in-depth research program (Bunge, 1972, p. 89).

The on-surface research program involves a growth in routine knowledge. It is a kind of working knowledge, without giving up the core of its beliefs. It allows the traditionally accepted theories of a scientific community to be improved by ironing out their anomalies and applying them to diverse fields. The in-depth research program offers a large-scale growth in knowledge. It provides substantially new ideas that uphold new views and perspectives from the information available. In the history of a science there are periods characterized by the predominance of one, or another, kind of growth.

The on-surface growth presents problems. It is blind and tends to paralyze scientific progress because the lack of alternative ideas. On-surface growth is necessary but 
insufficient. We would expect science to ripen when research seeks to be expansive, deep and solid. That is, when it not only widens its field but also goes deeper into it and organizes it in a better way. The in-depth growth implies the risk of sinking into uncontrolled speculation. The science evolves most favorably when it combines both-a phenomenon known as growth in volume (Bunge, 1972, p. 89).

The second contribution of Bunge (1983, p. 43) comes into the social field. Any research whose aim is a social fact, generated by men and women in his daily life, must tackle two main objectives: cognitive and utilitarian. The cognitive or intrinsic objective analyzes "what is." It provides scientific knowledge about the studied segment of social reality. The utilitarian or extrinsic objective is interested in "what should be." This second objective makes an active contribution to the technological progress that increases the social welfare of that reality.

From Bunge's perspective, research within social science can be defined as any activity or work performed by a researcher with the aim of obtaining further knowledge about a particular phenomenon. It implies the use of diverse theoretical versions for explaining, more or less successfully, the phenomenon. The relationship between the subjects who deal with the aforesaid phenomenon on a day-to-day basis must also improve by means of technical solutions, ideas, systems or models. They will increase their ability to understand the phenomenon and, thus, their capacity to handle it in their interests.

A social science should include both the cognitive and the utilitarian objectives. Both kinds of research must be closely related in a mutually dependent way to evolve correctly. The cognitive studies seek to understand the object under study. They base their research on the conceptual framework generated by utilitarian studies. Their theoretical premises help to build the initial hypotheses. They may also be a reference that upholds the explanations and considerations obtained from them. Likewise, the utilitarian studies provide a technical structure. It improves, to a greater or lesser extent, the subject-object relationship. The utilitarian approach cannot neglect the findings from the cognitive studies for its perfection, expansion or including innovation. The cognitive studies are the basis for utilitarian studies perfection, expansion or innovation. They provide a source of information about gaps, irregularities or peculiarities have not been dealt with in the utilitarian designs or models employed.

If the utilitarian or extrinsic objective of science is exaggerated, a gap between the research activity and the actual practical application will appear. In the same way, if the objectives of science focus on the pure knowledge of the subject being studied (cognitive), the obtained solutions will not enable to achieve greater control over the different problems encountered in practice. The results will really have a reduced application. Hence, both activities must be developed in a coordinated way.

\subsection{Management Accounting research: an adaptation of Bunge's theory}

Bunge distinguishes between two kinds of research. One depends on the objectives this research must achieve in a social science. It is known as cognitive and utilitarian. Another is that of on-surface and in-depth growth. It is used for explaining how science evolves. Bunge's doctrine allows us to establish a taxonomy of Management Accounting research, with four very clearly defined areas labeled A, B, C, and D (Table 1). 
Table 1

Taxonomy of research into Management Accounting

\begin{tabular}{lll}
\hline Target character (of the research) & \multicolumn{2}{l}{ Growth character (provided by the research) } \\
\cline { 2 - 3 } & On surface research & In depth research \\
\hline Utilitarian research & A & B \\
Cognitive research & C & D \\
\hline
\end{tabular}

Area A includes research focuses on the analysis of "what Management Accounting should be." It has a utilitarian objective that rests on a doctrinal or conceptual base. The corresponding scientific community generally accepts that base. A follows an on-surface growth.

Area B takes in research that uses new doctrinal or conceptual bases. It brings about an in-depth growth. B works on innovative proposals that arise under a utilitarian objective. That is, basically, it assumes the idea of "what Management Accounting should be."

Area $\mathrm{C}$ consists of publications that deal with "what Management Accounting is." $\mathrm{C}$ puts emphasis on the cognitive objective. It lies on one or several of the doctrinal bases established. It acknowledged within the research community of the discipline, which generate an on-surface growth.

Lastly, area D contains work that proposes, from a social viewpoint, new means of analysis. It also adopts new methodologies for the investigation. The last aim of D is to offer a theoretical explanation of "what Management Accounting is." It has both a cognitive objective and in-depth growth.

\subsection{Social research in Management Accounting}

In the last decade, a group of accounting researchers have been defending the following thesis: important scientific benefits can be obtained expanding the Management Accounting research activity from the economic dimension to the social dimension (Hopper and Powell, 1985; Roslender, 1996; Swanson and Gross, 1998). These benefits arise from the possibility of obtaining richer and deeper findings that satisfy better information needs in different social units.

Critical researchers recognize that to study social phenomenon is necessary to understand better the accounting in the real practice. For example, to consider the so-often underestimated role played by Management Accounting as a decisive factor in organizations, in particular, and in society, in general (Macintosh and Scapens, 1990; Thomas, 1989). Management Accounting guides and aids in formalizing the social processes and actions of organizations (Dermer, 1988; Nahapiet, 1988). Society also influences accounting science, practice and profession (Armstrong, 1985; Tinker, 1988).

As Belkaoui $(1985,1990)$ and Mathews (1993) affirm, the new social perspective has fundamental implications. We will now go on them using the Bunge's theoretical framework, exposed previously.

That perspective manifests a growing interest in variables and factors of sociological nature with influence in Management Accounting, "what should be"-utilitarian approach. It 
also implies a reorientation to an in-depth research. Following Bunge's theory it is classified into area B.

The origins of that interest lay in the concern for the generalizations made on the design of Management Accounting systems. Different authors (Cooper, 1988a, 1988b, 1988c, 1989, 1990a, 1990b, 1990c; Cooper and Kaplan 1988a, 1988b; Johnson and Kaplan, 1988; Kaplan and Atkinson, 1989), found inconsistencies in the empirical development of their cognitive-on-surface research (area C).

Most of accounting literature did not pay any attention to the cultural and contextual limits, as accounting research was mainly centered in agency theory (utilitarian-on-surface research, A). Agency theory was inspired by the conceptual position of marginalist and neoclassical economics (Berle and Means, 1932; Coase, 1937; Jensen, 1983; Milgrom and Roberts, 1988), which has been seen as a useful framework for giving objectivity to Management Accounting research.

Agency theory conceives Management Accounting as a pool of systems and techniques that provides economic information (Gago, 1996). Management Accounting information is useful because it reduces information asymmetries. It motivates agents for communication (Melumad and Reichelstein, 1987, 1989; Penno, 1984, 1990; Riordan and Sappington, 1987). Accounting information can be used for controlling the acts and outputs from the agent's decision-making (Antle and Demski, 1988; Baiman and Noel, 1985; Suh, 1988).

However, accounting researchers began to be conscious on the importance of introducing new variables concerning environment, human resources, power, politics, culture, social ideology, history, ethics, etc. into the design of Management Accounting models (Macintosh and Scapens, 1990; Neu, 1992; Oliver, 1991). They understood that the election of an accounting system can be governed by the search for power, the limitations on performing certain activities, the encouragement of particular lines of management and so on (utilitarian-in-depth research, B). All were economically oriented actions but with social implications. Previously, those issues were not a direct concern for the researchers. Studying them, they gain a better understanding, analysis and interpretation of certain phenomena with economic effects on the entity.

Technical prescriptions in Management Accounting are based upon economical and deterministically oriented macro proposals developed many years ago (Backer and Jacobsen, 1970; Beckett, 1964; Boter, 1958; Brett, 1940; Chandler, 1969, 1977; Davidson and Trueblood, 1961; Gordon and Shillinglaw, 1969; Guillespie, 1957; Hansen, 1951; Johnson, 1981; Kaplan, 1984; Mephan, 1988; Paris, 1959; Paton, 1943; Pollard, 1965; Reed, 1948). A group of accounting researchers adjusted those approaches to the heterogeneity and variety of different contexts, trying to be more close to the socio-cultural reality (Amat and Ripoll, 1997; Bayou, 1993; Foster and Gupta, 1990; Hogartth, 1993; Scapens and Roberts, 1993). These proposals are conducted using, generally, the case study method as basic tool to approximate the real context (Eisenhardt, 1989).

The research named "what Management Accounting is" has also experienced a relevant change influenced by the social conscience (D). The positivist theories opened up the possibilities for research that existed until the 1970s (Lawrence and Lorch, 1967; Lorch and Morse, 1979). They treated Management Accounting systems as an endogenous variable together with the organizational structure, production processes, environment, etc. (Bruns and Waterhouse, 1975; Hayes, 1977; Khandawalla, 1972). 
That research activity puts a high emphasis on proving any hypothesis and resorting to empirical research. Positivist theories divide systems in individual parts, using them as building blocks to construct knowledge about the whole (Quattrone, 2000). Proofs are based upon econometrics and statistics. Sometimes concerns regarding the adequacy of the method employed appear to become more important than the theory or the results achieved (called " $R^{2}$ syndrome") (Keys and Reding, 1992).

As a reaction, a group of academics defend the benefits of alternative research methods and epistemological perspectives (Czariawska-Joerges and Jacobson, 1989; Thomas, 1989). Interpretative and/or critical approaches are better suited to collecting qualitative aspects into a socio-economic science than alternative methods. Case study becomes a useful methodological tool for constructing new theories.

\subsection{Methods for the cognitive research}

Since late 1960s (Dyckman and Zeff, 1984; Watts and Zimmerman, 1978, 1979, 1990; Zeff, 1991), accounting research has revealed a growing interest in the cognitive objective (C research). It let the traditional utilitarian analysis having being completed. Indeed, empirical research in Management Accounting was not too used until the 1970s (Barrachina et al., 1999; Catelló et al., 1985; Ged, 1986).

The concern was how and why Management Accounting really performed in practice. Researchers investigated practices, relationships and roles of Management Accounting systems within organizations. These studies used the positivist methodology (Daft and Macintosh, 1978; Gordon and Miller, 1976; Hopwood, 1972).

An empirical approach was the use of Contingency Theory (Gordon and Narayanan, 1984; Ryan and Hobson, 1985). However, it did not turn out to be a successful trend. The static timeless was one of its main limitations. The analysis of multiple influencing factors associated with the context in which the company operates took on multilaterality (Otley, 1980; Weill and Olson, 1989).

From an epistemology perspective, the first cognitive approaches used in $\mathrm{C}$ are closely linked to the research methods used in econometrics and statistics. To obtain universal laws of the reality observed is their last purpose. They are predominantly economic oriented. They did not make use of methodologies developed in other areas of the social sciences.

Actually $\mathrm{C}$ research still maintains the foundations of neoclassical economics-economic rationality and balanced markets. It does not take into account other dynamic and political factors in order to understand how and why Management Accounting works in practice (Scapens, 1994).

However, that cognitive program, conducted by positivists, represented an important step forward for Management Accounting. It facilitates to complete the utilitarian objective of A. According to Bunge's theory, the combination of both objectives guarantees an adequate development for research in a social science. However, such condition is not sufficient for an adequate development of a social science as Management Accounting is.

Some researchers manifested an interest for the study of the social reality. They attempted to find out "what Management Accounting was" in the real world (C). Inconsistencies appear for supporting their findings with the existing theories (A). 
During 1980s, new theories were proposed (B) and, at the same time, new cognitive methods began to be applied (D) (Barrachina et al., 1999). As Roslender (1996) observed, this coordination had ever existed.

Thus, an increasing group of researchers defended that the empirical activity in Management Accounting (D) may be reinforced throughout case study methodology (Scapens, 1988). The reasons for supporting that utilization were diverse.

Case studies let researchers, and also practitioners, to understand the ways in which Management Accounting systems were used on a day-to-day basis, and on particular organizations. Case study methodology carried out an intensive examination of one single entity or a few of them. That examination provided a description of the present situation as regards aspects like the administrative and organizational context. Data were analyzed throughout qualitative descriptions and interpretations of the context of company studied (Kaplan, 1986).

Case study played an important role in understanding why problems appeared importing accounting theories and practices from other countries. For example, Japan accounting practices are heavily influenced by the national culture. In USA or Europe, they had to be adjusted to the new cultural parameters (Makido, 1992; Sskurai, 1990; Takeouchi and Nonanka, 1991; Urakawa, 1993).

\section{Future: consolidation of Management Accounting as a social science}

\subsection{Correcting existent gaps in research and in practice}

Research in a social science, and therefore research in Management Accounting, is an activity, or a work, that a researcher should perform with an open-mind. Its last purpose is to obtain further knowledge of a particular phenomenon.

The group of researchers that develops its activity, or work, in Management Accounting uses a wide variety of different theoretical frameworks (social, critical, psychological, etc.). Most of them are still emerging (B research). The pacific coexistence of different frameworks, especially those critical with the most popular or dominant, will guarantee the scientific progress in Management Accounting at long term.

Still there is an interface at the meeting points between the cognitive social research in Management Accounting (D) and the utilitarian branch (B). Quite frequently they operate without any connection, resting effectiveness to the overall scientific activity.

Moreover, to be really effective, management research must propose technical solutions for the practice, as a materialization of the ideas, systems or models generated in "what should be" (B) and to deal with "what is" (D). In general, social researchers, and especially critical researchers, aim to improve the relationships observed in each social phenomenon studied. They try to expand their ability to understand it and, therefore, their capacity to handle it and, including, change it. If there is a gap among what researchers study and what practitioners need, the success of the research is not guaranteed. To ignore practitioners' necessities implies to assume important risks of failure, not achieving the desired influence in the real world.

We agree on Quattrone's concern (2000, p. 134): “... although inter-disciplinary research has certainly brought new useful insights into accounting research ... its contribution has 
been made within the hierarchical scheme of the "Encyclopedia," avoiding an integration with the prior conventional perspectives. As a result of this, it has continued to maintain the fragmentation between areas of knowledge, generating some new problems, such as the incommensurability amongst divers theoretical positions (even within the "critical" side of accounting research) and the lack of dialogue with the economical and managerial approaches."

Accountants and managers should be provided with tools for acting in practice. This does not mean that researchers should be conditioned to practitioners' demands. We think that social researchers must provide feasible techniques looking for a positive social impact.

\subsection{Case study methods in social research}

Case study methods may be used for developing the research inside in-depth research (B and D). They help to solve particular and contextual problems observed in the cognitive research (D). The utilitarian perspective may be used to overcome the debating alternatives approaches, building critical theories, etc. (B). They also may contribute to the integration and coordination between the findings in $\mathrm{B}$ and $\mathrm{D}$.

Nevertheless, researching with this method implies accepting a series of limitations, facing to its validity and reliability. As Scapens (1990, p. 269) states: "a case study is only a small sample from which it is difficult to make a statistical generalization about the population from which it was drawn." This limits the current possibilities of case studies in the in-depth research (B and D).

Actually, case study research does not allow the researchers to extend their results. This limitation conditions its utilization of the findings to improve social reality, the subject-object relationship and the technical progress of the discipline. It must be solved facing to a future development of on-surface research (A and C) in social Management Accounting. In order to achieve an empirical trans-disciplinary framework, researchers must cooperate, looking for different feasible alternatives. We defend the validity of initiatives such as a process for compiling or summarizing case studies.

If case study research methods present important shortcomings for external validity, to look for an analytical generalization based upon shared knowledge from different cases may be a solution. It will consolidate the in-depth research (futures $\mathrm{A}$ and $\mathrm{C}$ ). The objective of analytical generalization would not be to translate particular results of any case study to another, but would facilitate to help or to guide other researchers to find or to recognize certain relationships in similar contexts. That also will let to develop the on-surface research (futures $\mathrm{A}$ and $\mathrm{C}$ ).

Different authors have defended the convenience of achieving a theoretical saturation with case studies (Eisenhardt, 1989; Lukka and Kansen, 1995). We think that the potential for generalizing from case studies is greater than is commonly considered. By generalization we mean the derivation of and argumentation for conclusions. They covered a number of cases of a certain type based on observations of the real world. That generalization is not statistical and automatic. The idea of generalization from research results in case studies could be substantiated by their "transferability" or "commonalties." A theory found in a case study must be tested through replications of the findings. Ideally, researchers could stop adding cases when theoretical saturation is reached. That is to say, the iteration process 
between theory and observation should stop when the incremental improvement of theory is minimal.

The results obtained in different individual or contextual studies must be available for comparisons, further analysis, etc. That proposal claims the need of "reliability" in case studies. To develop criteria (Harvard Business School-Bruns and Kaplan, 1987; Yin, 1993, 1994; McKinnon, 1988), to interchange experiences and problems detected during the realization of case studies, to interchange case protocols, etc. will contribute to improve the research design and its development.

\section{Conclusions}

As a general conclusion, we think that the research in a social science cannot center its objectives on the pure knowledge of the matter it studies (cognitive research). It needs obtaining solutions that can be used to achieve a greater control over the different social problems (utilitarian research). Both utilitarian and cognitive approaches must be developed and in a coordinated way. Actually still there is an interface at the meeting points between the current cognitive social research and the utilitarian branch.

After a stage of in-depth research conducted into social Management Accounting, a stage of on-surface research will appear. In the second stage the in-depth results are developed on, consolidated and applied, or alternatively, rejected. That avoids the occurrence of uncontrolled research speculation.

Research achievements must be converted into technical proposals. Vice versa, technical proposals should be proved in particular organizations. The accounting research observe their suitability to a certain organizational context, examining the potential problems of its implementation. A higher integration may be a barrier for the technical speculation without relevant findings.

Management, as a social science, needs an evolutionary, reflexive, and trans-disciplinary thinking. It has a theoretical and empirical dimension. Whilst the theoretical would focuses in the dialogue between different theoretical perspectives, the dialogue between different findings in particular case studies would support the empirical dimension.

Case study is proposed as the main research method, rejecting the rigorous use of universal laws and statistical and econometric generalizations. Case studies provide Management Accounting with a cognitive foundation for the reality studied. They permit accounting researchers to obtain a contextual perspective for interpreting accounting within organizations and society. Using case studies, to investigate how organizations and individuals make sense of accounting techniques is feasible. The understanding is deeper than the one obtained through the application of other alternative methods. Case studies do not seek just to obtain simple, universal relationships between concrete variables-they look into organizations. Case studies allow the research to theorize individually about different phenomena. They also let to take into account alternative relationships and different variables or factors. They generate a rich and diverse knowledge regarding the reality studied.

We agree on opinions manifested by Quattrone (2000), about not bringing new wine (e.g. new theoretical perspectives and methodologies). Social research in Management 
Accounting needs new bottles (e.g. a re-directional process may comprises an integration of theoretical and empirical findings).

\section{References}

Amat J, Ripoll V. Cambio organizativo y Control de Gestión: de un control personalista y burocrático a un control por resultados. IV Workshop en Contabilidad y Control de Gestión. Cadiz; 1997. p. 110.

Antle R, Demski J. The controllability principle in responsibility accounting. Acc Rev 1988;LXIII(4):700 18.

Armstrong P. Changing management control strategies: the role of competition between accountancy and other organizational professions. Acc Organ Society 1985;10(2):129 48.

Backer M, Jacobsen L. Contabilidad de Costes: un Enfoque Administrativo y de Gerencia. México: McGraw Hill; 1970.

Baiman S, Noel J. Noncontrollable costs and responsibility accounting. J Acc Res 1985;23(2):486 501

Baker CR, Bettner M. Interpretative and critical research in accounting: a commentary on its absence from mainstream accounting research. Critic Perspect Acc 1997;8(4):293 310.

Barrachina M, Gago S, Ripoll V. Evolución de la contabilidad de gestión como ciencia social. Revista de contabil idad y comercio, No. 224, 1999.

Bayou ME. Standardization issues in management accounting communication accounting. Aud Accountability $\mathbf{J}$ 1993;6(2):32 51

Beckett JA. Management accounting in the age of systems. NAA Bull 1964(April).

Belkaoui A. Accounting theory. San Diego: Harcourt Brace Jovanovich International Edition; 1985.

Belkaoui A. Judgment in international accounting. A theory of cognition, cultures, language and contracts. Con necticut: Greenwood Press; 1990.

Berle A, Means G. The modern corporation and private property. New York: McMillan; 1932.

Boter F. Teoría General de la Contabilidad Administrativa. Barcelona: Editorial Juventud; 1958.

Brett AC. The role of the accountant in the control of distribution costs. NACA Bull 1940(April).

Bruns W, Kaplan R. Introduction: field studies in management accounting. In: Bruns W, Kaplan R, editors. Accounting and management. Field study perspectives. Boston: Harvard Business School Press; 1987. p. 114

Bruns W, Waterhouse J. Budgetary control and organizational structure. J Acc Res 1975(Autumn):177 203.

Bunge M. Teoría y realidad. Barcelona: Editorial Ariel; 1972.

Bunge M. La ciencia, su método y su filosofía. Buenos Aires: Editorial Siglo Veinte; 1973.

Bunge M. La investigación científica. Barcelona: Editorial Ariel; 1983.

Cañibano L, Gonzalo JA. Los Programas de Investigación en Contabilidad. Revista de Contabilidad 1997;0:57 95.

Catelló E, Domenech C, Montesinos VY, Ripoll V. La Investigación en Contabilidad de Costes en el Período 1980 85. II Encuentro de PUC, 1985.

Chandler A. Strategy and structure: chapters in the history of the American industrial enterprise. Cambridge: MIT Press; 1969.

Chandler A. The visible hand. The managerial revolution in American business. Cambridge, MA: Harvard Uni versity Press; 1977.

Coase R. The nature of the firm. In: Stigler G, Boulding, editors (reediting). Readings in price theory. Homewood; 1982. p. 331 51. Económica 1937;4(November):386 405.

Cooper R. The rise of activity based costing part one: what is an activity based cost system? J Cost Manage 1988a(Summer):45 54

Cooper R. When you use machine hour costing? J Cost Manage Manufacturing Industry 1988b(Spring):33 9.

Cooper R. The rise of activity based costing part two: when do I need an activity based cost system? J Cost Manage 1988c(Fall):41 8.

Cooper R. The rise of activity based costing part three: how many cost drivers do you need and how do you select them? J Cost Manage 1989(Winter):34 46.

Cooper R. ABC. A need, not an option. Accountancy 1990a(September):86 8.

Cooper R. Activity based costing. Five steps to ABC systems design. Accountancy 1990b(November):78 80 .

Cooper R. Cost clasification in unit based and activity based manufacturing systems. J Cost Manage $1990 \mathrm{c}($ Fall):78 80 
Cooper R, Kaplan R. Measure cost right: make the right decisions. Harvard Bus Rev 1988a(September October):96 105 .

Cooper R, Kaplan R. How cost accounting distorts product cost. Manage Acc 1988b(April):20 6.

Czariawska Joerges B, Jacobson N. Budget in a cold climate. Acc Organ Society 1989;14(1/2):29 39.

Daft R, Macintosh N. A new approach to design and use of management information. Calif Manage Acc 1978(Fall):82 92.

Davidson HJ, Trueblood RM. Accounting for decision making. Acc Rev 1961(October).

Dermer J. Control and organizational order. Acc Organ Society 1988;13(1):25 36.

Dyckman T, Zeff S. Two decades of the Journal of Accounting Research. J Acc Res 1984(Spring):225 97.

Eisenhardt KM. Building theories from case study research. Acad Manage Rev 1989;14:532 51.

Foster G, Gupta M. Activity accounting: an electronics industry implementation. In: Kaplan R, editor. Measures for manufacturing excellence. Boston: Harvard Business School Press; 1990. p. 22568

Gago S. La Relación de Agencia en la Empresa. Análisis y Control de los Costes de Agencia. Madrid: Instituto de Contabilidad y Auditoría de Cuentas; 1996.

Ged A. Les Nouvelles Voies de Reserche en Comptabilité Managerial, Economies et Societes. Série: Sciences de Gestion 1986;8:147 80.

Gordon L, Miller D. A contingency framework for the design of accounting information systems. Acc Organ Society 1976:59 70 .

Gordon L, Narayanan V. Management accounting systems, perceived environmental uncertainty and organization structure: an empirical investigation. Acc Organ Society 1984;9(1):33 47.

Gordon MJ, Shillinglaw G. Accounting. A managerial approach. Richard D. Irwing; 1969.

Guillespie C. Cost accounting and control. NJ: Prentice Hall; 1957.

Hansen P. Handborg I Regnskabsvaesen. Branner og Korch; 1951.

Hayes D. The contingency theory of managerial accounting. Acc Rev 1977(January):29 39.

Hogartth R. Accounting for decisions and decisions for accounting. Acc Organ Society 1993;18(5):407 24.

Hopper TM, Powell A. Making sense of research in the organizational and social aspects of management account ing. J Manage Studies 1985:429 65.

Hopwood A. An empirical study of the role of accounting data in performance evaluation. J Acc Res 1972(Suppl): 15682.

Hopwood A. The archaeology of accounting. Acc Organizational Society 1987;12(3):207 34.

Howard TP, Nikolai L. A attitude measurement and perceptions of accounting faculty publication outlets. Acc Rev 1983;58(4):765 76.

Jensen M. Organization theory and methodology. Acc Res 1983;LVIII(2):319 39.

Johnson T. Toward a new understanding of nineteen century cost accounting. Acc Rev 1981;LVI(3):510 8.

Johnson T, Kaplan R. La contabilidad de costes. Auge y caída de la contabilidad de gestión. Barcelona: Plaza \& Janés; 1988

Kaplan R. The evolution of management accounting. Acc Rev 1984;LIX(3):390 418.

Kaplan R. The role for empirical research in management accounting. Acc Organ Society 1986;11(4/5):429 52.

Kaplan R, Atkinson A. Advanced management accounting. NJ: Prentice Hall; 1989.

Keys D, Reding K. Stadistical process control: what management accountants should know. Manage Acc 1992(Jan uary).

Khandawalla P. The effect of different types of competition on the use of management controls. $\mathrm{J}$ Acc Res 1972;10(2):285 95 .

Kuhn TS. Structure of scientific revolutions. Chicago: University of Chicago Press; 1962.

Lakatos I. Historia de la Ciencia y sus Reconstrucciones Racionales. In: Historia de la Ciencia y sus Reconstruc ciones Racionales. Madrid: Editorial Tecnos; 1974. p. 977.

Lakatos I. La Falsación y la Metodología de los Programas de Investigación Científicos. In: La Crítica y el Desarrollo del Conocimiento. Ediciones Grijalbo; 1975. p. 20324

Lapsley I, Mitchell F. Management accounting research: the change agenda. Manage Acc Res 1994;5(3/4):215 9.

Lawrence P, Lorch J. Differentiation and integration on complex organ. Admin Sci Quart 1967;12:1 47.

Lorch J, Morse J, Organization and their members: a contemporary approach. New York: Harper \& Row; 1979.

Lukka K, Kansen E. Methodological themes: the problem of generalizability: anecdotes and evidence in account ing. Acc Aud Accountability 1995(J 8):71 91.

Macintosh N, Scapens R. Structuration theory in management accounting. Acc Organ Society 1990;15:455 77. 
Makido T. Tendencias Recientes en las Prácticas Japonesas de Gestión de Costes. In: Monden Y, Sakurai M, editors. Métodos Japoneses de Contabilidad. Contabilidad de Gestión en el Nuevo Entorno Industrial. Madrid: Productivity Press; 1992. p. 315

Mathews M. Socially responsible accounting. London: Chapman \& Hall; 1993.

McKinnon R. Reliability and validity in field research: some strategies and tactics. Acc Aud Accountability J 1988;1(1):34 54.

Melumad N, Reichelstein S. Centralization versus delegation and the value of communication. J Acc Res 1987;25(Suppl):1 17

Melumad N, Reichelstein S. Value of communication in agencies. J Econ Theory 1989;47:334 68.

Mephan M. The eighteen century origins of cost accounting. Abacus 1988;24(1):55 74.

Milgrom P, Roberts J. Economic theories of the firm: past, present and future. Can J Econ 1988;XXI(3):444 58 .

Morgan G. Accounting as reliability construction: towards a new epistemology for accounting practice. Acc Organ Society 1988;13(5):477 85 .

Nahapiet J. The rhetoric and reality of accounting change: a study of resource allocation. Acc Organ Society 1988;13(4):333 58.

Neu D. The social construction of positive choices. Acc Organ Society 1992;17(3/4):223 37.

Oliver L. Accountants as business partners. Manage Acc 1991(June):40 2.

Otley D. The contingency theory of management accounting: achievement and prognosis. Acc Organ Society 1980;5(4):413 28.

Paris G. El Precio de Coste en la Industria. Editorial Francisco Casanova; 1959.

Paton WA. Manual del Contador. Editorial UTHEA; 1943.

Penno M. Asymmetry of pre decision information and managerial accounting. J Acc Res 1984, Spring;22(1):177 91.

Penno M. Accounting systems, participation in budgeting, and performance evaluation. Acc Rev 1990;65(2):303 14.

Perera M. Towards a framework to analyze the impact of culture on accounting. Int J Acc 1989;24:42 56

Pollard S. Factory discipline in the industrial revolution. Econ Hist Rev 1965:254 71.

Popper K. La Lógica de la Investigación Científica. Madrid: Editorial Tecnos; 1967.

Popper K. Objective knowledge. An evolutionary approach. Oxford: The Crandon Press; 1973.

Quattrone P. Constructivism and accounting research: towards a trans disciplinary perspective. Acc Aud Account ability J 2000;13(2):130 55.

Reed, WL. Cost accounting concepts, introductory statement. Acc Rev Enero 1948.

Riordan M, Sappington D. Information, incentives, and organizational mode. Quart J of Econ 1987:243 63.

Roslender R. Relevance lost and found critical perspectives on the promise of management accounting. Critic Perspect Acc 1996;7:533 61.

Ryan B, Hobson J. Management accounting. A contemporary approach. United Kingdom: Pitman; 1985.

Scapens RW. Research into management accounting practice. Manage Acc 1988(December):26 8.

Scapens RW. Researching management accounting practice: the role of case study methods. Brit Acc Rev 1990;22:259 81

Scapens RW. Never mind the gap: towards an institutional perspective on management accounting practice. Manage Acc Res 1994;5:301 21.

Scapens RW, Roberts J. Accounting and control: a case study of resistance to accounting change. Acc Organiza tional Society 1993;4:1 32

Sskurai M. The influence of factory automation on management accounting practices: a study of Japanese com panies. In: Kaplan R, editor. Measures for manufacturing excellence. Boston: Harvard Business School Press; 1990. p. 3962

Stegmüller. The structuralist view of theories. New York: Spring Verlag; 1979.

Suh Y. Noncontrollable costs and optimal performance measurement. J Acc Res 1988, Spring;26(1):154 68.

Swanson Z, Gross NJ. A comparison of academics', practitioners', and users' perspectives toward the research of accounting practice. Critic Perspect Acc 1998;8:467 85.

Takeouchi H, Nonanka I. El Nuevo Proceso de Desarrollo de Nuevos Productos. Harvard Deusto Bus Rev 1991;1:23 36.

Thomas A. The effects of organizational culture on choices of accounting methods. Acc Bus Res 1989;19(76):363 78. 
Tinker T. Panglossian accounting theories: the science of apologizing in style. Organ Society 1988;13(2):165 89. Urakawa T. How bridgestone creates new business through new research. Long Range Planning 1993(April):17 23. Watts R, Zimmerman J. Towards a positive theory of the determination of accounting standards. Acc Rev 1978(January):112 34

Watts R, Zimmerman J. The demand for and supply of accounting theories: the market for excuses. Acc Rev 1979(April):273 305.

Watts R, Zimmerman J. Positive accounting theory: a ten years perspective. Acc Rev 1990(January):131 56.

Weill p, Olson MH. Managing investment in information technology: mini case ex. MIS Quart 1989;13(1):3 15.

Yin RK. Applications of case study research, in applied social research methods series, vol. 34. London: Sage Publications; 1993.

Yin RK. Case study research, applied social research methods series, in applied social research methods series, vol. 5. London: Sage Publications; 1994.

Zeff S. Prólogo. In: La Investigación en Contabilidad. La Hipótesis de Eficiencia del Mercado, J. Tua. Madrid: I.C.A.C., Ministerio de Economía y Hacienda; 1991. p. 135. 